\title{
The Integration Of Personal Financial Knowledge Into Multi-Disciplines: The First Step Of Reinforcement
}

Dan Yates, University of Findlay, USA

Chris Ward, University of Findlay, USA

\begin{abstract}
This study represents an extension of longitudinal studies regarding personal financial literacy. Graduating college students must have a financial plan in place as they enter the workforce along with a "game plan" on how to attack their college debt. A college personal finance course can help each student develop their personalized financial plans. However, other college or university disciplines can help reinforce sound financial principles in their courses. If you think about it, "money" is a common denominator that links everyone together in our society. Shouldn't our universities and colleges be responsible for helping their students become excellent "money managing" stewards?
\end{abstract}

Keywords: Interdisciplinary Learning; College Debt; Personal Financial Literacy; Interactive Learning

\section{LITERATURE REVIEW}

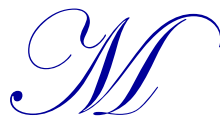

any college students will have college debt but most will have no idea on how to best approach paying off their debt. Upon graduation there are many life choices such as buying or renting a house, buying a new or used car, leasing or financing a vehicle, trying to build credit, or deciding to marry or wait. All of these choices involve money and can further complicate issues regarding debt. What responsibilities do we have as educators to help students become better educated on handling their finances? The researchers believe that all college students must take a personal finance course and learn the basic principles of managing money. Another important aspect to learning is that other disciplines can add to this body of knowledge by assigning projects, papers, and experiential learning exercises to reinforce sound financial principles.

\section{FINANCIAL ISSUES FACING COLLEGE GRADUATES}

Some college graduates are having a difficult time in finding a job. Shierholz, Sabadis, and Wething (2012) reported high unemployment rates (10.4 percent in 2010 and 9.4 percent in 2011) for college grads and noted that the "under-employment" rate was 19.8 percent in 2010 and 19.1 percent in 2011 . Although college grads may struggle in landing a job, it may not be in their college major. Andrew Sum (2012) reported that "among college graduates under the age of 25 and working in 2011, 37.8 percent were not working in a job that required a college degree..." (p. 7).

Shierholz et al.'s (2012) review of the labor market noted that "the cost of higher education has grown far more rapidly than median family income, leaving students with little choice but to take out loans, which, upon graduating into a labor market with limited job opportunities, they may not have the funds to repay" (p. 1).

Reed and Cochrane (2012) reported that an estimated two-thirds (66\%) of the 2011 graduating college seniors averaged $\$ 26,600$ in loans and about one-fifth of graduates' debt was comprised of private loans. The state averages (2011) for debt at graduation from four-year colleges ranged from $\$ 17,250$ to $\$ 32,450$. 
The Golden Financial Services' study by Debt Statistics (2013) found that the average credit card debt carried by undergraduate college students was $\$ 3,173$. Twenty percent of 18 to 24 year-olds reported they had some type of debt hardship while $84 \%$ of undergraduates indicated they needed more advice in the areas of financial education and debt management. The majority of students wished they had more financial education opportunities in high school, forty-one percent of college students have at least one credit card and around 50\% of the undergraduates have four or more credit cards. This compares with the statistics that the U.S. consumer carries an average of 3.5 credit cards and that $51 \%$ of the U.S. population has at least two credit cards. It was noted that $65 \%$ of the students pay off their credit card balances each month and the remaining students carry an average balance of $\$ 452$ per credit card. It was interesting to note that only $7 \%$ of the monthly college spending used credit cards while the remaining used cash and debit cards. Some of the encouraging news was that one-third of student credit cards had a zero balance in 2011-12; $41 \%$ of families reported student card balances of less than \$500; and only 3\% carried a balance greater than $\$ 4000$. This recent trend of college students carrying low credit card balances should reduce the debt hardship cited above for the 18 to 24 year-olds.

\section{FINANCIAL ISSUES FACING ADULTS}

College students are not alone in facing financial woes. Their parents and grandparents are dealing with their own financial issues such as the lack of retirement savings, debt, working during retirement, and planning for escalating health care costs. The University of Chicago conducted landline and cellphone survey interviews with 1,024 people aged 50 and older nationwide (Sendensky 2013). About half of the survey participants reported feeling secure about retirement savings as opposed to feeling anxious. It was reported that one in six reported had less than $\$ 1,000$ in retirement savings while only one in four working had no other savings plan outside of Social Security. Twelve percent of the unretired people reported borrowing from a 401(k) or other retirement plan in the past year. This could be an indication the respondents' expenses had exceeded their incomes for that period. Although 29 percent reported at least $\$ 100,000$ in retirement savings, many believed that amount was insufficient to generate enough income from investments to meet their retirement needs. The survey also noted that $82 \%$ of workers 50 and older were somewhat likely to work for pay in retirement while $47 \%$ expect to retire three years beyond their original retirement date based on their best estimate at age 40 . Those respondents earning less than $\$ 50,000$ a year and those without health insurance indicated they were more likely to put off their retirement plans.

Too many people approaching retirement will not have adequate savings to maintain their current standard of living throughout retirement. Along with poor savings, many in the US will enter retirement with debt which includes home mortgages, car loans, credit card balances, and other personal debt. The US average debt is $\$ 78,030$. The average age that Americans expected to be "debt free" was age 53 (Alhanati, 2012). Although Americans wish to be debt free, in reality, it isn't happening. Many people are bringing debt into their retirement years which places additional burden on income that may be either fixed or limited.

Below is the average total debt by generational group in 2012 (Alhanati, 2012):

\begin{tabular}{|lcl|}
\hline \multicolumn{1}{|c}{ Group } & Debt Amount & Age Range \\
\hline Greatest generation (pre-1946) & $\$ 38,043$ & ages 66 plus \\
Baby boomers (1946-1964) & $\$ 101,951$ & ages 47 to 65 \\
Generation X (1965-1985) & $\$ 111,121$ & ages 30 to 46 \\
Generation Y (1978-1990) & $\$ 34,765$ & ages 19 to 29 \\
\hline
\end{tabular}

Yates and Ward (2013) surveyed the perceptions and the reality of retirement of two groups in Northwest Ohio: those planning to retire within five years and those who are currently retired. The purpose was to determine the extent to which the respondents were prepared for retirement on various areas regarding financial planning.

Their results agreed with earlier research that more workers will stay in the workforce longer due to their lack of confidence in having enough money to live comfortably during their retirement years (Carrns, 2010; Malonebearch \& Langeland, 2011). More than half of the workers reported having less than $\$ 25,000$ in total investments and $70 \%$ had less than $\$ 1,000$ in savings and investments. This supports earlier reports that baby boomers are not saving enough for retirement (Rosnic \& Baker, 2010; Wolff, 2002; Weller \& Wolff, 2005). Some 
of the retirees indicated having debt which was less than $\$ 100,000$. Over $50 \%$ of the retirees indicated they worked during retirement and over $25 \%$ indicated the reason for working was due to the decrease in their investments from the economic downturn. This poses problems for recent college graduates trying to find employment with more retirement aged people indicating they will be staying on their jobs longer.

\section{FAILED FINANCIAL EDUCATION EFFORTS}

Each generation is dealing with how to best manage their money in an ever changing environment. For many years, financial education has not been successful in teaching and applying financial methods that impact behavior that leads to effective money management practices.

The research on failed financial educational efforts has been well documented. Mandell and Klein (2009) note that high school students who took a personal finance course "did not report better financial behavior several years later than youth who did not take the course" (p. 18). Cole and Shastry (2008) reported similar results on adults who attended public schools. There were no better financial outcomes whether they took the personal finance course or not.

Willis (2012) stated "that another reason financial education is unlikely to produce household financial well-being is that consumers' knowledge, comprehension, skills, and willpower are far too low in comparison with what our society demands" (p. 128). Willis believes that decisions regarding financial areas such as credit, insurance, and investments demand some degree of financial knowledge and skills, but also include "numeracy, linguistic literacy, and the ability to make informed predictions about the future" (p. 128). The U.S. Government Accountability Office (GAO) reported in 2006 that about half of the U.S. adults cannot read beyond the eighth-grade level. Willis concludes "that is simply too large a gap for financial literacy education to bridge" (p. 128). Fox, Bartholomae, and Lee (2005) cited that recent levels of bankruptcy, high consumer debt, and poor saving may result from low financial literacy levels.

Another important point in Willis' research is that many people have "unpredictable and generally insufficient income and assets" (p. 130) which to apply any financial education. Many Americans (over 40\%) reported they have difficulty in making ends meet (Pew Research Center for the People \& the Press, 2009). Lambert and Henley (2009) found that most part-time employees and 14\% of full-time employees had fluctuating work hours from week to week. This makes financial planning very difficult.

\section{DEFINITION OF FINANCIAL EDUCATION}

What is financial education? After reviewing various definitions, the authors believe the 2005 Organization for Economic Co-operation and Development (OECD) recommendations on financial capability were consistent with on their definition of financial education: "the process by which financial consumers/investors improve their understanding of financial products, concepts and risks and, through information, instruction and/or objective advice, develop the skills and confidence to become more aware of financial risks and opportunities, to make informed choices, to know where to go for help, and to take other effective actions to improve their financial well-being" (OECD, 2005).

Baumann and Hall (2012) stressed that "financial education focused on consumption cannot serve the citizen; rather, financial education must be rooted in the needs of the individual" (p. 508). The authors believe that the "needs" of the individual are best suited by applying those concepts found in the OECD definition of financial education. The learner should also be actively engaged in applying those concepts in relation to their own lives as individuals.

Taylor, Tisdell, and Forte (2012) conducted a nationwide online survey of financial educators to examine teaching beliefs, related curriculum, and teaching strategies. One of the areas the survey focused on was "classroom pedagogical practices utilized and those found to be most effective" (p. 532). It was found that the methods considered most effective by the financial educators were: (1) drawing on learners' financial experiences; (2) engaging learners in small group and whole class discussions; (3) sharing aspects of the educator's financial 
experience; and (4) including stories or examples featuring members of diverse groups. These methods supported the more interactive approaches to learning financial concepts in which learners will need to practice and apply to their own lives (p. 537). It was interesting to note that lecturing and discussing community issues were in the middle of the effectiveness evaluation. The methods identified as being the least effective were the "use of cultural art forms, field trips, online activities, and homework" (p.535). The study results supported the use of verbal and written student feedback in evaluating the educators' teaching effectiveness.

Mandell and Klein (2007) examined the low financial literacy scores among young adults even after taking a personal finance course. They found that the low scores were related to a lack of motivation to learn and retain these skills. The research was based on the 2006 national Jump\$tart survey of high school seniors.

Mandel and Klein stressed that "student aspiration or motivation is a key characteristic of financial literacy" and that "successful programs must focus on relating the importance of understanding basic financial literary to the students' ability to reach and potentially exceed their level of aspiration" (p. 106). They noted that "students retain little of what they learn in personal finance and money management classes because they do not perceive that it is relevant to their lives" (p. 108). Mandel and Klein referenced the book Engaging Minds: Motivation \& Learning in America's Schools in which the author David Goslin (2003) stated learners will become engaged and stay engaged with tasks if they find some degree of relevance with that subject matter.

The analysis of the Jump\$tart data (2007) indicated that "successful financial literacy is related to students' perceptions of future goals including a college degree, a professional job, or a higher salary" (p. 113). They also found that setting clear and obtainable goals were often missed from most financial literacy programs. "Programs must relate the course content to goal obtainment and demonstrate how understanding and implementing financial principles will add significant value to their lives" (p. 113). Lastly, it is important that instructors stress that students "are responsible for their futures and that the happiness of these futures can vary dramatically based upon their actions" (p. 114).

Children can learn through play and digital media has resulted in increasing more sophisticated games that can engage youth and encourage learning. Katie Salen is the lead designer of the New York City's first public school based on game design principles. Salen stated that game designers really understand the problem of engagement and its close connection to feedback, rewards, motivation, and goal setting which represent the key characteristics of the way people learn (MacArthur Foundation, 2009).

Other studies embrace the positive learning results of interactive games. Research from the University of Florida using students playing educational video games resulted in higher scores on benchmark exams than students not playing the games. The gains by the experimental group were 8.07 points as compared to the control group gains of 3.74 points (Riedel, 2008). In another study, the state of West Virginia piloted the Financial Football game with teachers in 17 high schools. Prior to the game, students were tested and 53 percent answered half or more of the basic questions pertaining to finance and financial tools. After playing the online Financial Football game, 92 percent of the students correctly answered the questions along with other more sophisticated content areas such as questions about interest rates and risk. The improved scores were a result of the students being subjected to the information repeatedly as they tried to improve their scores in the game" (Treasurer, State of West Virginia, 2010).

Jessica Trybus, Director of Edutainment for Carnegie Mellon University's Entertainment Technology Center, stated that the interactive learning process is what makes games enjoyable. Trybus stressed the importance of actively being engaged with the game while student minds experience the issues of resolving challenging scenarios and the satisfaction of accomplishing them. Game-based learning tools move individuals from passive listening to the type of active problem solving needed to tackle financial issues head-on (Trybus, 2011).

\section{MULTI-DISCIPLINE APPROACH TO FINANCIAL EDUCATION}

Baumann and Hall (2012) stated that "any framework for financial education should be oriented...towards the individual learner..." (p. 512) and is a lifelong undertaking. Hanrahan (2009) believed that learner-centered education should be an intrinsic part of curriculum that is explored across all disciplines and courses. The learner 
should be exposed to critical engagement of concepts regarding prudent living, risk aversion, avoidance, and acceptance in life. Hanrahan noted that core financial concepts should be explored through multiple disciplinary perspectives such as mathematics, geography, history, literature, statistics, civic, and social sciences.

Willis (2012) cited there are alternative pathways to financial well-being such as math education and instruction. Numeracy was highly correlated with saving for retirement (Banks, O'Dea, \& Oldfield, 2010), mortgage performance (Gerardi, Goette, \& Meier, 2010), and wealth (Smith, McArdle, \& Willis, 2010). Gerardi et al. (2010) found in their study on loan defaults that low levels of numeracy were strongly related to mortgage default. They found that knowledge of financial concepts had no relationship to defaults and therefore concluded that financial education programs that teach both math skills and financial concepts may have positive effects.

One of the suggestions from the Roundtable Session Highlights from the 2012 Financial Management Association (FMA) Annual Meeting on "The Role of Professors in Improving Financial Literacy" was for faculty to work within their department and/or collaborate with other departments to create a general education class that addresses personal financial issues (Eades, Fox, Keown, \& Staten, 2013). They suggested this material would promote in-class discussions and be useful in an online course environment. Another important outcome was moving financial literacy toward a goal of financial capability. Eades et al. stated that financial capability is "achieved by combining financial knowledge with access to and experience using financial products" (p. 142). It is all about making decisions. They cited the Darden School's Financial Literacy Program for High School Students, which was initiated in 2010, in order to be compliant with the Virginia state law requiring a one-credit financial literacy course upon graduation. The program used the "case method" as opposed to a lecture-based approach. The case method requires students to work with actual financial problems, work collaboratively in synthesizing various sources and to apply that information in solving real-world problems. Eades et al. noted the benefits of this approach as it is interactive, iterative, and has a dynamic format.

\section{METHODOLOGY}

The researchers presented at a regional SoTL Scholarship of Teaching and Learning conference in Michigan with the theme "Making Student Learning Visible." Using a workshop approach, a power point presentation discussed the importance of financial literacy for college students. An exercise handout was provided for each of the participants. The handout listed various topic areas found in personal finance as well as a list of typical academic courses found in university curriculums (see Chart A below). There were six people participating in the exercise. Using the exercise handout, the participants were instructed to find and select a personal finance topic from the list and then select a course of study that they have taught. Each participant then developed a written assignment/exercise for the course of study that would "reinforce" the personal finance concept.

Chart A: Sample Portion of the Exercise Handout

\begin{tabular}{|l|l|}
\hline $\begin{array}{l}\text { Instructions: From the list of personal finance topics on the left, select a topic and find a course of study in which an exercise } \\
\text { could be developed that would reinforce the personal finance topic within that course of study. }\end{array}$ \\
\hline \multicolumn{1}{|c|}{ Personal Finance Topic Areas } & \multicolumn{1}{c|}{ Course of Study } \\
\hline Careers (searching for a job) & English \\
\hline Resumes, cover letters, interviewing & Speech \\
\hline Goal Setting & Computer Science \\
\hline College debt & Religious Studies \\
\hline Saving and compounding interest & Philosophy \\
\hline Retirement planning & Mathematics \\
\hline Credit issues and credit cards & Theater \\
\hline Wills, trusts, and estates & Political Science \\
\hline Purchasing & Psychology \\
\hline Budgets and spending plans & Sociology \\
\hline Risk management & Accounting \\
\hline Insurances (auto, life, home) & Money \& Banking \\
\hline Investment fundamentals & Business \& Society \\
\hline Real Estate (buying a home or rental) & Ethics \\
\hline Financial discipline & Communications \\
\hline
\end{tabular}




\section{RESULTS}

courses.

Below are several examples from the workshop experience in applying personal financial topics in other

- $\quad$ Course: Introduction to Accounting

Example: Purchasing a Car

From the seller's perspective, students would explain how a car dealer makes money on a sale of a car. The student should discuss mark-up on the price of the car, servicing a car, and financing the sale. From the buyer perspective, what is the total cost of buying a car?

Students should comment on the various costs such as insurance, financing, licensing, depreciation, etc. All of the costs and concepts could be incorporated in conjunction with journal entries and basic accounting principles. For example, explain the impact of interest and depreciation expense on net worth/equity.

- Course: Contemporary Mathematics $\quad$ Example: Personal Tax Returns

The instructor discusses the content areas found on personal tax returns. Students are provided different made-up scenarios. Some of the relevant topics such as tuition deduction and credit, child care credit, itemized deductions, etc. were selected to keep the interest of the student. The instructor discussed how CDs, savings accounts, and mortgages could impact their tax return. Additional instruction was used in calculating interest income from investments using online calculators. Examples of using compounding interest could also be used in an algebra course.

- $\quad$ Course: Government; Civics

Example: How a Budget Sets Priorities and Limits Choices

The New York Times has on their website an interactive graphic that allows users to attempt to balance the federal budget. Students can choose to cut particular budgets or change policies (e.g., raise the retirement age) that would result in savings.

Through the exercise students will learn:

1. Policies have specific effects such as raising retirement age would require people to work longer;

2. How much money is spent indicates how important something is; and

3. Money spent one place cannot be spent another; students will learn that a budget will limit choices.

The student will apply their decisions at a national level and then consider how it would impact them on a personal level. If government wants to spend more, then it needs more revenue (i.e., more taxes) or reduce expenditures. If a person wants more income, then they have to work more. However, you must remember that raising taxes has its limits and you can only work so many hours in a week.

- Course: Introduction to Religion Example: Proverbs and the Handling of Money

Instructions: Select at least five verses from the book of Proverbs that relate to money. Briefly discuss each of the verses and identify you can change or adopt a behavior that reinforces the meaning of the verse.

Explain why those behaviors have importance to you.

- Course: Political Science $\quad$ Example: Implications of Over-Spending

Instructions: Find some articles relating to the impact of overspending by government. What impact does this overspending have on society, the taxpayer's disposable income, the economy, business and its growth, and other relevant areas? What are the implications of over-spending by you? Develop several recommendations for the government to adopt in becoming more financially responsible. Could these recommendations also be applied to individuals? Why or why not? 
- $\quad$ Course: Sociology $\quad$ Example: Money \& Marriage

Instructions: Research articles that discusses how poor money management habits can lead to problems within a marriage. Develop a list of money managing techniques that can lead to financial success. From the list, select two techniques that you plan to adopt. Explain why those techniques are important to you.

The examples above reinforce many important concepts in financial education. It impacts the students on a personal level which should maintain their interest in learning and applying the financial concepts. The exercises are relevant to their needs. These exercises could be designed in a case format with the students sharing their results in small discussion groups. This approach is consistent with the guidelines of Bloom's taxonomy of educational objectives (i.e., knowledge-based goals, skills-based goals, and affective goals).

\section{CONCLUSION}

The theme of the SoTL Teaching and Learning conference was Making Student Learning Visible. Our workshop provided a forum for participants to develop learning opportunities for students through meaningful assignments/exercises and identify various venues to showcase student knowledge. This demonstration to the community and others will hopefully add value to our society that our next generation will better manage their personal finances and will not have to rely on external support through taxation.

Our earlier question: Shouldn't our universities and colleges be responsible for helping their students become excellent "money managing" stewards? Our answer is absolutely YES. We can accomplish by doing the following:

- $\quad$ Using interactive curricular approaches to teaching financial education which engages the students;

- $\quad$ Drawing on learners' financial experiences during discussions;

- $\quad$ Engaging learners in small group and whole class discussions;

- $\quad$ Sharing aspects of the educator's financial experience;

- Include stories or examples featuring members of diverse groups as they relate their experiences in financial situations; and

- Use goal setting techniques which will motivate students and encourage them to have a vision for the future.

As a result of these learning activities, our students over time should demonstrate lower college debt, reduced credit card balances, lower car loan amounts, increased number of students working part-time during college, awareness of building credit scores and impact on interest rates on borrowed monies, paying cash instead of borrowing money, delaying major purchases, increased savings rates, building financial wealth at a faster pace, etc. These examples provide "visible" and quantifiable outcomes. Our students will have written financial plans on how they will manage their debt and how they will begin saving for their financial future. These financial plans are hard evidence that our students are applying their financial knowledge to their personal lives and may help them secure financial loans from banking institutions.

We recommend that educators from the various disciplines use the methods found in Taylor et al.'s (2012) study which embrace the more interactive teaching approaches in which learners practice and apply financial concepts to their own lives. Eades (2013) stated that financial capability is "achieved by combining financial knowledge with access to and experience using financial products" (p. 142). It is all about making "good" decisions and engaging in critical thinking. Eades et al. also note the benefits of this approach as it is interactive, iterative, and has a dynamic format. "Programs must relate the course content to goal attainment and demonstrate how understanding and implementing financial principles will add significant value to their lives" (p. 113). This philosophy above somewhat mirrors the criteria found in "writing across the curriculum." Hanstedt (2012) stated that "properly engaged - that is, designed and supported effectively by the instructor — writing becomes evidence of critical thinking on the part of students." Perhaps we could apply many of the principles found in writing across the curriculum and re-coin it to fit our situation; such as learning and writing about "financial literacy across the 
curriculum." Lastly, it is important that instructors stress that the students "are responsible for their futures and that the happiness of these futures can vary dramatically based upon their actions" (p. 114).

\section{FUTURE RESEARCH}

Our next step is to get the message out to our colleagues. We plan to develop a series of workshops which are very similar to our earlier workshop. The goal is to create awareness of the importance of financial education as a student learning outcome and to create learning opportunities within other courses and disciplines. Educators need to be encouraged to create assignments that engage the students and motivate them to learn and apply financial concepts.

Educators need to remember that (1) we have savings problem; (2) we have a spending problem; (3) we have a debt problem; and (4) we have a behavioral problem and start saying "NO" to ourselves regarding purchases. This should be motivation enough for educators across all disciplines to begin a change in their classrooms in helping their students become more financially literate and secure.

\section{AUTHOR INFORMATION}

Dan Yates is an Associate Professor of Business at the University of Findlay. He is currently Chair of Quantitative \& Global Business Studies and serves as Chair of the University Committee on Committees. His teaching interests include personal finance, entrepreneurship, leadership, organization development, and business strategy. Yates holds a PhD degree in Management from Northcentral University. He also has a MBA from University of Dayton, a Master of Organization Development degree from Bowling Green State University, and a BS in Accounting from Tiffin University. He completed the NxLevel Certification Course for Instructor Certification for teaching business plans at the Innovation Center (Ohio University). He has 30 years industrial and governmental experience. E-mail: yates@ findlay.edu (Corresponding author)

Dr. Chris Ward is an Associate Professor of Business at The University of Findlay. She is currently the Chair of Business Administration programs and serves on the General Education, Faculty Development and Faculty Affairs committees and as an accreditation co-chair of HLC Criterion 4. Professor Ward holds the following degrees: University of Sarasota, EdD, Organizational Leadership; MBA and BS in Business Administration from the University of Findlay. She is also a Six Sigma Black Belt, a 2008 and 2010 Ohio Partnership for Excellence Examiner, and NxLevel Instructor. Her areas of research include student engagement and leadership, civility, and personal branding. E-mail: cward@findlay.edu

\section{REFERENCES}

1. Debt Statistics. (2013, March 13). Retrieved October 17, 2013 from http://nomorecreditcards.com/aboutus/credit-card-debt-statistics/

2. Alhanati, J. (2012, August 9). The generational debt gap. Retrieved November 6, 2013 from http://www.investopedia.com/financial-edge/0812/the-generational-debt-gap.aspx

3. Banks, O' Dea, C., \& Oldfield, Z. (2010, November). Cognitive function, numeracy and retirement saving trajectories. Economic Journal, 120(548), F381-F410.

4. Baumann, C., \& Hall, T. (2012). Getting Cinderella to the ball: putting education at the heart of financial education. International Journal of Consumer Studies, 508-514.

5. $\quad$ Carrns, A. (2010). Taking stock (and coming up short). U.S. News \& World Report, 22-28.

6. Cole, S., \& Shastry, G. (2008). If you are so smart, why aren't you rich? The effects of education, financial literacy and cognitive ability on financial market participation. (working paper) Harvard Business School.

7. Eades, M. K., Fox, J., Keown, A., \& Staten, M. E. (2013). The role of professors in improving financial literacy roundtable session highlights from the 2012 FMA Annual Meeting. Journal of Applied Finance, 138-144.

8. Fox, J., Bartholomae, S., \& Lee, J. (2005). Building the case for financial education. Journal of Consumer Affairs, 195-214. 
9. Gerardi, G. L., \& Meier, S. (2010, April). Financial literacy and subprime mortgage delinquency: Evidence from a survey matched to administrative data. (Working Paper) Federal Reserve Bank of Atlanta.

10. Hanrahan, D. (2009). The philosopher king, the gentleman of leisure and the challenge of modernity: An education to serve the needs of the state and an education to serve the needs of the individual. MLitt, National University of Ireland.

11. Hanstedt, P. (2012). Reforming general education: Three reasons to make writing across the curriculum part of the conversation. Liberal Education, 98(4), 48-51.

12. Ito, M., Horst, H., Bittanti, M., Boyd, D., Herr-Stephenson, B., Lange, P., et al. (2009, June). Living and learning with new media. Retrieved February 5, 2014 from http://mitpress.mit.edu/sites/default/files/titles/free_download/9780262513654_Living_and_Learning.pdf

13. Lambert, S., \& Henly, J. (2009, May). Scheduling in hourly jobs: Promising practices for the Twenty-First Century economy. Retrieved from http://www.mobilityagenda.org/home/page/Scheduling-in-Hourly-jobsPromising-Practices-for-the-Twenty-First-Century-Economy.aspx

14. Malonebeach, E., \& Langeland, K. (2011). Boomers' prospective needs for senior centers and related services: A survey of persons 50-59. Journal of Gerontological Social Works, 54, 116-130.

15. Mandell, L., \& Klein, L. (2007). Motivation and financial literacy. Financial Services Review, $105-114$.

16. Mandell, L., \& Klein, L. (2009). The impact of financial literacy education. Association for Financial Counseling and Planning Education, 15-21.

17. OECD. (2005). Improving finanical literacy: Analysis of issues and polices. Paris: OECD.

18. Reed, M., \& Cochrane, D. (2012). The project on student debt. Student Debt And The Class Of 2011, $2-8$.

19. Riedel, C. (2008, June 16). UCF study finds video games increase student achievement. Retrieved February 2014 from http://thejournal.com/articles/2008/06/16/ucf-study-finds-video-games-increase-studentachievement.aspx

20. Rosnic, D., \& Baker, D. (2010). The impact of the housing crash on the wealth of the baby boom cohorts. Journal of Aging \& Social Policy, 22, 117-128.

21. Sedensky, M. (2013, October 22). Poll: Half of older workers delay retirement plans. High cost of living, financial setbacks cited, p. A7.

22. Shierholz, H., Sabadish, N., \& Wething, H. (2012, May 3). The Class of 2012 labor market for young graduates remains grim. Retrieved October 16, 2013 from http://www.epi.org/publication/bp340-labormarket-young-graduates/

23. Smith, J., McArdle, J., \& Willis, R. (2010, November). Financial decision making and cognition in a family context. Economic Journal, 120(548), F363-F380.

24. Sum, A. (2012). Forthcoming Paper. Centerfor Labor Market Studies at Northeastern University.

25. Taylor, W. E., Tisdell, E. J., \& Sprow Forte, K. (2012). Teaching financial literacy: A survey of community-based evidence. International Journal of Consumer Studies, 531-537.

26. Treasurer, State of West Virginia. (2010). Results or pre-testing and post-testing of high schools participating in Financial Football. (Unpublished raw data).

27. Trybus, J. (2012). Game-based learning: What it is, why it works, and where it's going. Retrieved February 2014 from http://www.newmedia.org/game-based-learning--what-it-is-why-it-works-and-where-itsgoing.html

28. U.S. GAO. (2006, September). Credit cards: Increased complexity in rates and fees heightens need for more effective disclosures to consumers. Retrieved from http://www.gao.gov/new.items/d06929.pdf

29. Weller, C., \& Wolff, E. N. (2005). Retirement income: The crucial role of social security. Washington, D.C.: Economic Policy Institute.

30. Willis, L. E. (2012). Financial education: Lessons not learned and lessons learned. Financial Education, 125-134.

31. Wolff, E. N. (2002). Retirement insecurity: The income shortfalls awaiting the soon-to-retire. Washington, D.C.: Economic Policy Institute.

32. Yates, D., \& Ward, C. (2013). The perception versus the reality of retirement: Are you ready to retire? Journal of Business \& Economics Research, 2(1), 1-9. 
NOTES 